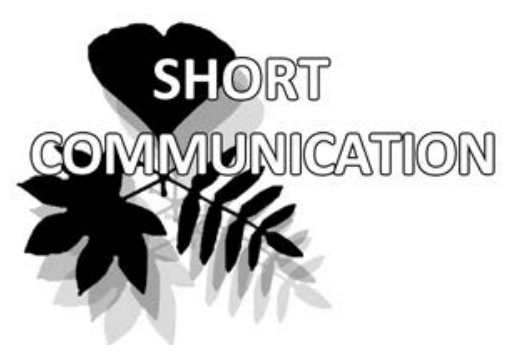

\title{
Note on Cyathodium (Hepaticae) in Vietnam
}

\author{
Eugeny Borovichev ${ }^{1 *}$, Vadim Bakalin² \& Van Sinh Nguyen ${ }^{3}$
}

Eugeny Borovichev ${ }^{1 *}$

e-mail: borovichyok@mail.ru

Vadim Bakalin ${ }^{2}$

e-mail: vabakalin@gmail.com

Van Sinh Nguyen ${ }^{3}$

${ }^{1}$ Institute of North Industrial Ecology Problems of Kola Science Center RAS, Apatity, Russia

${ }^{2}$ Botanical Garden-Institute FEB RAS, Vladivostok, Russia

${ }^{3}$ Institute of Ecology and Biological Resources, Vietnam Academy of Science and Technology, Ha Noi, Vietnam

* corresponding author

Manuscript received: 19.08 .2018

Review completed: 15.01.2019

Accepted for publication: 17.01.2019

Published online: 21.01.2019

\begin{abstract}
A B S T R A C T
The distribution of Cyathodium in Vietnam and Indochina is poorly known. The present account provides new data on distribution of C. cavernarium in the country and reviews other reports. The morphological description, based on Vietnam material, as well as data on ecology and distribution overview of the taxon is provided. All taxa known in Vietnam are characterized by Gondwana-land distribution pattern and stretches from Africa through Indian subcontinent to Malesia.

K e y w o r d s : Cyathodium, Hepaticae, Indochina, Vietnam, Gondwana-land distribution pattern
\end{abstract}

\section{P E 3 Ю M E}

Боровичев Е.А., Бакалин В.А., Ван Шинь Нгуен. Заметка о роде Cyathodium (Нераticae) во Вьетнаме. Распространение видов рода Cyathodium во Вьетнаме и Индокитае в целом до сих пор остается слабо известным. Приводятся новые данные о распространении C. cavernarium в стране и обсужАаются указания Аругих виАов рода. Приводится морфологическое описание, основанное на образце из Вьетнама, также обсуждается экология и распространение вида. Все представители рода, известные во Вьетнаме, характеризуются Гондванским распространением и простираются от Африки через ИнАийский субконтинент Ао Малезии.

Ключевые слова: Cyathodium, Нераticae, Индокитай, Вьетнам, Гондванское распространение
Cyathodium is relatively small genus of thallose hepatics that counts 13 extant species with the most of them regarded as 'good' taxa in Söderström et al (2016). All representatives of the genus are drought-intolerant, perennating by tubers and lives in moist and commonly shaded sites in rock crevices and soils and sometimes possess weedy nature. The genus may be characterized in general as having pantropical distribution, with southernmost records in Western Australia and northernmost in Southern Europe and South Japan (Frey \& Stech 2009). The majority of Cyathodium taxa shows narrow distributional ranges (Srivastava \& Dixit 1996) that may be regarded as the consequence of its distribution within habitats spreading from where could be problematic. The striking feature of at least majority of Cyathodium taxa is the luminescent nature that makes the recognizing of taxa relatively easy.

Cyathodium is not rare in Vietnam. The first report of this genus was published as far as by Bescherelle (1892) in the list of hepatics collected by M. Balansa in Tonkin Bay area and identified by F. Stephani (printed as M. Stephani in Bescherelle, 1.c.). The latter list contains the mention of "Cyathodium balansae Steph. nov. spec. Ouonlis (N 30)" - the obvious nomen nudum that was never validated after. Three years later Stephani (1895) published the list of Hepaticae Africanae, where he described the general distribution of C. cavernarum also as "Tonkin (Balansa)" (1.c.: 300). Since no
C. cavernarum (but C. balansae only!) was mentioned in original paper devoted to Balansa collection (Bischerelle 1892) the only reason we can explain this situation was the change of Stephani opinion who regarded his previous C. balansae as the same (synonymous) with $C$. cavernarum.

Overlooking the circumstance described above, Pócs (1965) reported Cyathodium balansae as nomen nudum and as the only species of Cyathodium in Vietnam. Later, Bakalin et al. (2016) found the synonymy of C. balansae with C. smaragdinum in Srivastava and Dixit (1996) uncritically followed to the latter authors and reported C. smaragdinum for Vietnam. It worth to be mentioned the basis for the later synonymy is quite unclear for us (moreover Bakalin was not able to find in $G$, where it should be kept and to check the identity). Bakalin et al. (2016) overlooked the report by Stephani (1895), whereas Shu et al. (2017) probably overlooked the preceding mention in Bescherelle (1892) and reported C. cavernarum in their list with the reference for Stephani (1895), but retained in the latter the report of C. smaragdinum based on Srivastava and Dixit (1996), thus reported two taxa virtually based on the same specimen.

Another report of Cyathodium is that $C$. aureonitens by Srivastava \& Dixit (1996) who cite Vietnam in the general distribution of the taxon, but do not provide specimens examined for the country nor references for primary report. As the result by now there are three mentioned taxa, all re- 
garded as undoubted reports in Shu et al. (2017), despite reports of two taxa are based on the same specimen that seems to be lost, and the origin of third species report is unclear. Meantime, it worth to be noted the distribution of all of three mentioned taxa in Vietnam is possible and the special attention should be paid to this genus discovery in the course of field researches.

In the course of joint Russian-Vietnamese investigation of liverwort component in the flora of North Vietnam Bakalin, Nguyen and Klimova visited Hoang Lien Son Range where found 'luminescent' thallose liverwort named in the field as Cyathodium sp. The later laboratory study by Borovichev has showed the specimen belong to C. cavernarum - one of the most widely distributed taxa of the genus. To provide information on the first undoubted report of Cyathodium in Vietnam (and Indochina as the whole, since there are no reports of this genus for other countries in the region) and the identification key to differs all reported taxa in the country below we put the description based on collected material and the key, with accompanying note on ecology of the taxon.

Key to species of Cyathodium reported for Vietnam

1. Plants with hairy involucres; spores spinate, spines 5-7 $\mu \mathrm{m}$ long ......................... Cyathodium aureonitens (Griff.) Mitt.

- Plants without hairy involucres; spores baculate or granu-

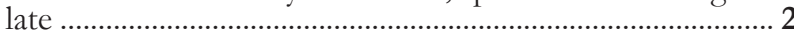

2. Thalli ultimate branches often fan-shaped from the rapid dichotomy; spore spherical, with granulate surface ................ Cyathodium smaragdinum Schiff.

- Thalli ultimate branches irregularly dichotomously branched, non fan-shaped; spore spherical, with baculate surface . Cyathodium cavernarum Kunze

Cyathodium cavernarum Kunze in Lehmann, Nov. Stirp. Pug. 6: 18. 1834. - Cyathodium africanum Mitt., J. Proc. Linn. Soc., Bot. 22: 327. 1887. - Cyathodium mexicanum Steph., Rev. Bryol. 36: 139. 1909. - Cyathodium barodae Chavan, Bryologist 11: 57. 1937.

Illustrations: Srivastava \& Dixit, 1996 (p. 186, fig. VIII; p. 187, fig. XIX); Bischler-Cause et al., 2005 (p. 138, fig. 93; p. 144, fig. 97 (C, D)).

Description (Fig. 1): Thalli delicate, very thin; small; ultimate branches $2-6(-8) \mathrm{mm}$ long, $0.8-2.0 \mathrm{~mm}$ wide; not fragrant; forming more or less loose patches or small mats; irregularly dichotomously branched, non fan-shaped; segments sublingulate to rarely obcordate, fringed towards apex; apex rounded; thallus upper surface smooth; pores numerous, visible with hand lens as points, dorsal epidermis very delicate; color of upper surface pale green to yellowish green, glistening; thallus margins green, without secondary pigmentation; plane; thin. Dorsal epidermis delicate, hyaline, chlorophyllose; cells polygonal, (30-)35-65 $\times(22-) 25-40(-45) \mu \mathrm{m}$, thin-walled cells, trigones absent; oil-cells scattered in epidermis, brownish, 15-20 × 13$18 \mu \mathrm{m}$; pores simple, smaller toward apex slightly elevated above epidermis; hole small, 12.5-20.5 $\mu \mathrm{m}$ in diameter, surrounded by $2-4$ concentric rings of $3-5(-7)$ elongated cells in each, cells thin-walled, radial walls not thickened. Aerenchyma well-developed, loose, occupying all thallus height in the middle; air-chambers in single layer in the middle; large, empty, in cross-section polygonal, 168$210 \mu \mathrm{m}$ wide and 56-75 $\mu \mathrm{m}$ high; without photosynthetic filaments; ventral tissue absent; oil-cells yellowish. Midrib thallus segment absent; ventral side flat. Rhizoids numerous on ventral surface; smooth, hyaline; two types: large and straight-walled and narrower and sinuous, but not tuberculate. Ventral scales near thallus apex, never not projecting laterally; hyaline; tiny, filamentous to lanceolate, 3-7 cells long; 80-150 $\mu \mathrm{m}$ long and 25-48 $\mu \mathrm{m}$ wide; appendage absent; marginal slime papillae present.

Sexual condition terminal-autoicous. Androecia in cushion shaped antheridial receptacle lateral-terminal, between two lobes or between female involucres; disc-shaped, $0.1-0.15 \mathrm{~mm}$ in diameter. Gynoecia arising between two shorter branches on the upper part of thallus; obovoid; sac-shaped, bivalve slightly exerted from the thallus apex, mouth with a series (2-3 rows) of elongated, thick-walled, brown cells. Spores dark-brown, 40-55 $\mathrm{m}$, spherical, with baculate surface (only young spores are present in the sporophytes, however the present here characteristics are based on spores that were found over older part of thallus). Elaters 4-8 per capsule; reddish-brown; 2-3 spiral; 250$280 \mu \mathrm{m}$ long, $8-10 \mu \mathrm{m}$ width at middle.

Specimen examined: Vietnam, Lao Cai Province, Sa $\mathrm{Pa}$ District, Ban Khoang Commune, Hoang Lien Range, $22^{\circ} 23^{\prime} 54^{\prime \prime} \mathrm{N}, 103^{\circ} 47^{\prime} 07^{\prime \prime} \mathrm{E}, 1410 \mathrm{~m}$ alt., evergreen south subtropical mountain forest in stream valley, open mesic cliff crevice, 16.IV.2017, V.A. Bakalin, K.G. Klimova \& V.S. Nguyen V-2-9-17 (VBGI, duplicate in INEP).

Differentiation. Among the regional taxa of Cyathodium, C. cavernarum is morphologically most similar to C. smaragdinum. It differs from $C$. smaragdinum in: (1) thalli irregularly dichotomously branched, non fan-shaped vs. often fan-shaped in C. smaragdinum; (2) thalli ultimate branches sublingulate to rarely obcordate, fringed towards apex vs. shortly obcordate in C. smaragdinum; (3) spore spherical, with baculate surface vs. spherical, with granulate surface in C. smaragdinum. Cyathodium aureonitens is characterized by dorsal pores distributed only in anterior thallus part; dioicous, female plants comparatively larger than male plants; hairy involucres and spinose spores.

Ecology. Sciophilous meso-hygrophytic acidophyte; mountainous species commonly occurring in middle to higher belts near to oro-subtropical and, even, oro-south temperate communities. The species prefer moist shady niches and caves where growing on this fine soil.

Distribution. Nearly Pantropic species known from Southeast Asia (including Malesia), Indian subcontinent (including Himalaya and its spurs), Central and northern South America (Srivastava \& Dixit 1996, Bischler-Cause et al. 2005, Long 2006). In nearby areas recorded from Myanmar. Throughout Asia limited in distribution by southern spurs of Himalaya and southwestern spurs of Tibetan Plateau, should be likely observed in southwestern China. Southeastward of Asian continent spread area as far as to Java where occurs in similar conditions. The distribution of two other taxa recorded in Vietnam (C. smaragdinum and C. aureonitens) is somewhat similar to the former, although 


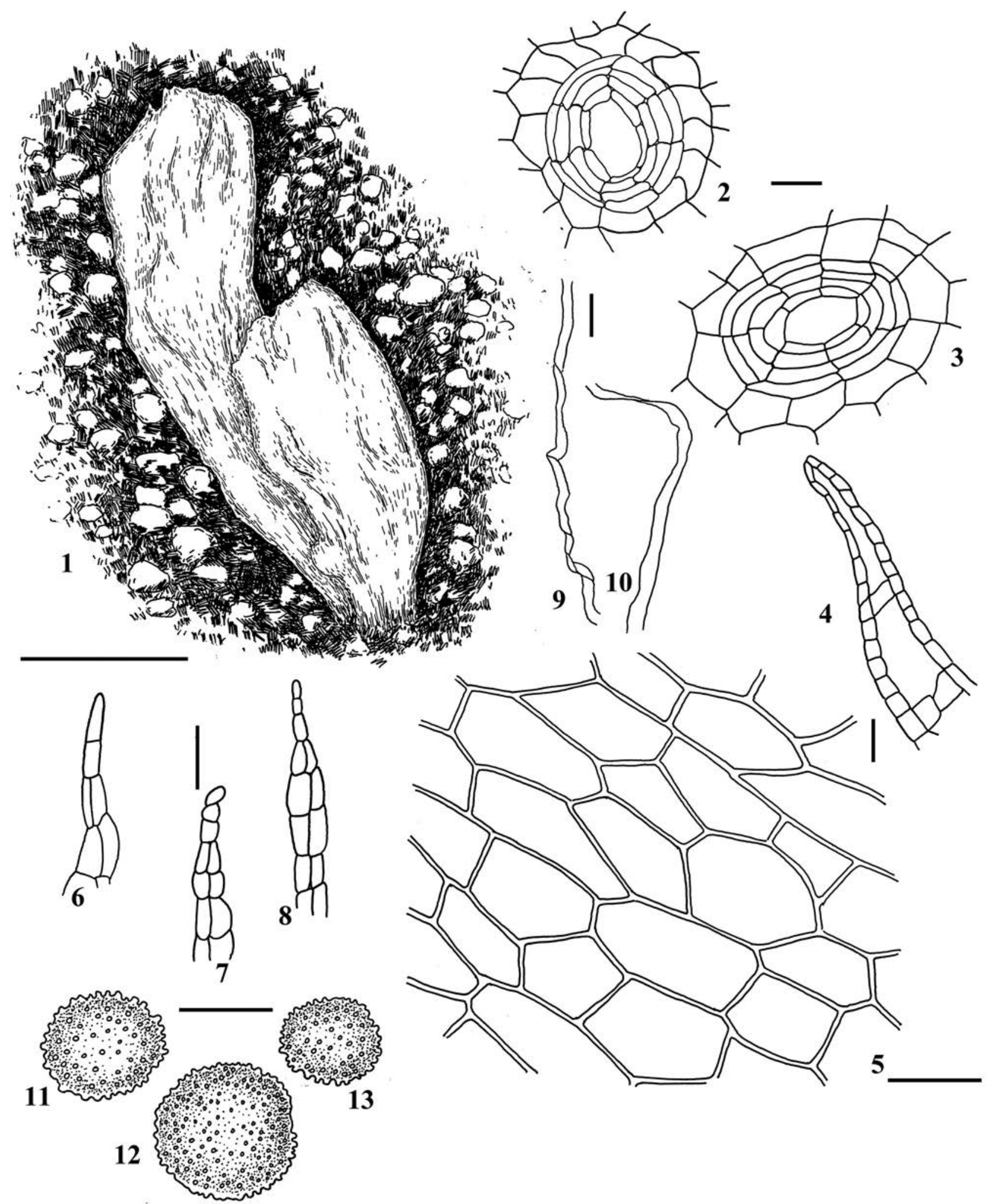

Figure 1 Cyathodium cavernarum Kunze: 1 - habit of plant, dorsal view; 2-3 - air-pore from dorsal epidermis of thallus; 4 - part of thallus cross-section; 6 - part of thallus dorsal epidermis; 6-8 - ventral scales; 9 - rhizoids; $10-12$ - spores. Scale bars: $2 \mathrm{~mm}$ for 1; 100 $\mu \mathrm{m}$ for 9-10; $70 \mu \mathrm{m}$ for 4; $50 \mu \mathrm{m}$ for 6-8; $40 \mu \mathrm{m}$ for 5, 10-12; $10 \mu \mathrm{m}$ for 2-3. All from Bakalin, Klimova and Nguyen, V-2-9-17 (VBGI)

both does not occurs in the New World. The African-Indian-Indochina distribution of all three taxa suspect very old distribution pattern of Gondwana-land origin.

\section{ACKNOWLEDGEMENTS}

Authors are grateful to Mr. M. Bakalin for line drawings preparation. The study was partly supported by the collaboration project between Vietnam Academy of Science and 
Technology and Far Eastern Branch of the Russian Academy of Sciences (no. BAHT17-002) and "Patterns of altitudinal zonation of hepatics in East and South-East Asia" (VAST. HTQT.NGA.02/17-18). The providing of the permissions for collecting and transferring of material via national borders by the Institute of Ecology and Biological Resources of Vietnam Academy of Science is greatly appreciated.

\section{LITERATURE CITED}

Bakalin, V.A. \& V.S. Nguyen 2016. The checklist of liverworts (Hepaticae) and hornworts (Anthocerotae) of Vietnam updated based on literature survey. Tap Chi Sinh Hoc 38(4):480-491.

Bescherelle, E. 1892. Énumeration des hépatiques récoltées au Tonkin par M. Balansa et déterminées par M. Stephani. Revne Bryologique 19:13-15.

Bischler-Cause, H., S.R. Gradstein, S. Jovet-Ast, D.G. Long, N. Salazar Allen 2005. Marchantiidae. Flora Neotropica 97: 264.

Frey, W. \& M. Stech 2009. Marchantiophyta, Bryophyta, Anthocerotophyta. In: Syllabus of Plant Families (W. Frey, ed.), pp. 1-257, Borntraeger, Stuttgart.

Long, D. 2006. Notes of Himalayan Hepaticae 3: New records and extensions of range for some Himalayan and Chinese Marchantiales. Cryptogamie, Bryologie 27(1):119-129.
Pócs, T. 1965. Prodrome de la bryoflore du Vietnam. Az Egri Tanárképzó Föiskola Tudományos Közlleményei 3: 453-495.

Shu, L., Y.-L. Xiang, X.-F. Cheng, Y.-M. Wei, J. Wang, L.N. Zhang, W. Li, X.-B. Yin, W.-P. Zhang, C.-X. Zhao, T. Peng, T. V. Do, T. N. Lu \& R.-L. Zhu 2017. New Liverwort and Hornwort Records for Vietnam. Cryptogamie, Bryologie 38(4):411-445.

Söderström, L., A. Hagborg, M. von Konrat, S. Bartholomew-Began, D. Bell, L. Briscoe, E. Brown, D.C. Cargill, D.P. Costa, B.J. Crandall-Stotler, E.D. Cooper, G. Dauphin, J.J. Engel, K. Feldberg, D. Glenny, S.R. Gradstein, X. He, J. Heinrichs, J. Hentschel, A.L. Ilkiu-Borges, T. Katagiri, N.A. Konstantinova, J. Larraín, D.G. Long, M. Nebel, T. Pócs, F. Felisa Puche, E. Reiner-Drehwald, M.A.M. Renner, A. Sass-Gyarmati, A. Schäfer-Verwimp, J.G.S. Moragues, R.E. Stotler, P. Sukkharak, B.M. Thiers, J. Uribe, J. Váňa, J.C. Villarreal, M. Wigginton, L. Zhang \& R.-L. Zhu 2015. World checklist of hornworts and liverworts. PhytoKeys 59:1-828.

Srivastava, S.C. \& R. Dixit 1996. The genus Cyathodium Kunze. Journal of the Hattori Botanical Laboratory 80:149-215.

Stephani, F. 1895. Hepaticae africanae. Botanische Jahrbucher für systematik, Pflanzengeschichte und Pflanzengeographie 20: 299-321. 